\title{
Local scour around a bridge pier under ice-jammed flow condition - an experimental study
}

\author{
Jun Wang ${ }^{1}$, Zhixing Hou ${ }^{1}$, Hongjian Sun ${ }^{1}$, Bihe Fang ${ }^{1}$, Jueyi Sui ${ }^{2}$, Bryan Karney ${ }^{3}$ \\ ${ }^{1}$ College of Civil and Hydraulic Engineering, Hefei University of Technology, 193 Tunxi Road, Hefei, Anhui, China. \\ ${ }^{2}$ School of Engineering, University of Northern British Columbia, 3333 University Way, Prince George, BC, Canada. \\ ${ }^{3}$ Department of Civil Engineering, University of Toronto, Canada. \\ ${ }^{*}$ Corresponding author. E-mail: Jueyi.sui@unbc.ca
}

\begin{abstract}
The appearance of an ice jam in a river crucially distorts local hydrodynamic conditions including water level, flow velocity, riverbed form and local scour processes. Laboratory experiments are used for the first time here to study ice-induced scour processes near a bridge pier. Results show that with an ice sheet cover the scour hole depth around a bridge is increased by about $10 \%$ compared to under equivalent open flow conditions. More dramatically, ice-jammed flows induce both greater scour depths and scour variability, with the maximum scour depth under an ice-jammed flow as much as $200 \%$ greater than under equivalent open flow conditions. Under an ice-jammed condition, both the maximum depth and length of scour holes around a bridge pier increase with the flow velocity while the maximum scour hole depth increases with ice-jam thickness. Also, quite naturally, the height of the resulting deposition dune downstream of a scour hole responds to flow velocity and ice jam thickness. Using the laboratory data under ice-jammed conditions, predictive relationships are derived between the flow's Froude number and both the dimensionless maximum scour depth and the dimensionless maximum scour length.
\end{abstract}

Keywords: Ice jam; Ice cover; Riverbed deformation; Local scour; Bridge pier.

\section{INTRODUCTION}

Ice jams can represent key hydrologic elements in temperate and polar rivers, occurring repeatedly during some winters. The appearance of an ice jam increases the flow's wetted perimeter, thus increasing a reach's resistance, decreasing local velocities and increasing water levels, possibly even to the point of causing ice flooding. Moreover, an ice jam alters the transport of sediment by temporarily impounding water, thus deforming the riverbed compared to under open flow conditions. The riverbed scour under an ice-jammed flow condition may precipitate the failure of hydraulic structures such as bridges (Beltaos, 2012; Buzin et al., 2015; Munck et al., 2017). Indeed, bridge piers affect the transportation of both sediments and river ice, inducing variations in local ice jam thickness and water level (Sui et al., 2010; Wang et al., 2017). Since velocity profiles under icecovered conditions differ from those under open flow conditions, local scour processes around bridge piers are often profoundly altered. Based on field observations at the Melvin Prince Ship-lock on the Mississippi River, Carr noted the formation of a huge scour hole in front of the foundation of a ship lock (Carr and Tuthill, 2012). Although this scour hole was repaired/filled, it reappeared within a year. A laboratory model indicated that even a 100-year flood under an open flow condition could not create such a large scour hole. However, under an ice-covered flow conditions, a huge scour hole around the foundation of the Ship-lock was developed with a smaller discharge. As the size of a scour hole is an important indicator of the turbulent intensity around a hydraulic structure, so the maximum depth of a scour hole is a helpful index of the stability and safety of such a structure (Link et al., 2020; Yang et al., 2020).

To satisfy engineering requirements, considerable work has explored the mechanisms of local scour in the vicinity of bridge piers under the open flow conditions and various relations have been derived to predict the maximum scour depth around a single bridge pier (Alemi et al., 2019; Sonia Devi and Barbhuiya, 2017; Hosseini and Amini, 2015; Zaid et al., 2019). Recent work has considered local scour around multiple piers or pile groups (Amini and Mohammad, 2016; Khaple et al., 2017) including the impact of grain size and flow structure on local scour (Abou-Seida et al., 2012; Schendel et al., 2018). However, much less work has considered local scour under ice-covered conditions.

Clearly, ice covers and ice jams inevitably add an extra solid boundary to the flow and increase its wetted perimeter. Under ice-covered conditions, the location of the maximum flow velocity migrates closer to the riverbed increasing the bed shear stress around bridge piers. Thus, the riverbed scour depth around bridge piers under an ice-covered flow condition is expected to increase (Wang et al., 2008). The first research work regarding local scour process under ice-covered flow condition was conducted by Bacuta and Dargahi (1986). Based on clear-water washout experiments, Bacuta and Dargahi investigated local scour process around a circular bridge pier under an ice-covered flow condition, arguing that the resulting scour depth was much greater than under open flow conditions. Ackerman et al. (2002) also investigated the impact of ice cover on local scour around a circular bridge pier performing both clear-water tests and live bed tests. Ackerman and Shen claimed that the maximum scour depth under an ice-covered flow condition increased about 25 to $35 \%$, comparing to under an open flow condition. Munteanu (2004) did experiments under different boundary conditions: free surface (FS), total ice-cover (TIC) and partially ice cover along flume walls (2PIC). Surprisingly, the local scour process around a pier under the condition of partially ice-covered flow was found to be the strongest, and the maximum scour depth around a pier 
under the condition of partially ice-covered flow being about $55 \%$ more than that under the open flow condition. Hains and Zabilansky (2004), Zabilansky et al. (2006) investigated the local scour around bridge piers, pointing out that the maximum depth of scour hole under the smooth ice-covered flow condition is about $10 \%$ greater than that of under the open flow condition. They also noted that the depth of scour holes around bridge piers increases with the increase in the roughness of model ice cover. Sui et al. (2009) assessed the scour patterns caused by submerged jet under conditions of open flow, smooth ice-covered flow and rough ice-covered flow. Their results showed that the scour depth under rough ice-covered condition exceeds that under the open flow condition and that decreasing the flow depth increases the scour depth. Wu et al. $(2014,2015)$ also studied local scour finding that an increase in the particle size of the armor-layer resulted in a reduction in the depth of scour holes. Under rough ice-covered flow condition, the scour depth was found to be the largest. With the increase in grain size, the maximum scour depth decreases. However, the maximum scour depth will increase with the increase in the dimensionless shear stress. Namaee and Sui (2019a, 2019b, 2019c, 2020) assessed the impacts of ice cover on the scour process around 2 side-by-side bridge piers, again showing that the local scour around side-by-side bridge piers was greater than that around a singular bridge pier. Their results also indicated that more sediment deposited at the downstream side of those sideby-side bridge piers comparing to that of singular bridge pier. Regardless of flow cover, the vertical turbulent intensity was highest exactly over the channel bed and diminished towards the flow surface, implying that the shear stress is greatest on the channel bed causing sediment to be transported at a higher rate. Additionally, under the same flow condition, the value of turbulence kinetic energy increased with the pier size.

All previous studies regarding the impact of ice cover on the local scour processes around bridge piers/abutments have been conducted in the laboratory using a sheet ice cover. However, the extreme riverbed deformation occurs under the ice-jammed flow condition in natural rivers (Sui et al., 2000). Yet, flow conditions and local scour processes around bridge piers under ice-jammed conditions have not yet been investigated. To address this and to provide engineers with some knowledge regarding the mechanism of local scour process at piers, the current conceptual study reports on laboratory experiments on the impact of an ice jam on the pier scour processes, for the first time measuring and modeling the interaction between the channel bed deformation and ice accumulation around a bridge pier.

\section{EXPERIMENT SETUP}

Experiments have been carried out in a laboratory flume at Hefei University of Technology. As sketched in Figure 1, the flume is $26.68 \mathrm{~m}$ long and $0.4 \mathrm{~m}$ wide. In total, 22 observation cross sections (CS) along the flume with an equal spacing distance of $1.2 \mathrm{~m}$ have been setup. Between CS-2 and CS-22, a sand bed with an initial thickness of $10 \mathrm{~cm}$ was formed. The median grain size $\left(d_{50}\right)$ of sand bed material is $0.71 \mathrm{~mm}$ and the inhomogeneity coefficient $\eta$ is 1.61. All experiment runs be- long to clear-water scouring. The sand bed was leveled before each experimental run and the slope was maintained at 0 . An ice hopper which was located between CS-4 and CS-5, was used to add model ice particles into the flume. At the downstream cross section CS-20 which is $2.24 \mathrm{~m}$ away from the outlet of the flume, a Styrofoam panel with the length of $1 \mathrm{~m}$ was placed on water surface to initiate the formation of an ice jams. Due to limitation of laboratory conditions and budget, researchers normally use other material to model ice. Up to date, the commonly used materials to model ice particles or ice floe in laboratory experiments include paraffin, polystyrene, polyethylene, polypropylene (Beltaos, 1995; Healy and Hicks, 2007; Urroz and Ettema, 1992; Urroz et al., 1994; Wang et al., 2015). In the present experimental study, model ice particles used are made of polyethylene with the mass density of 0.918 $\mathrm{g} / \mathrm{cm}^{3}$, which is nearly the same as the mass density of natural ice of $0.917 \mathrm{~g} / \mathrm{cm}^{3}$. Model ice particles have a flat-ellipsoid shape. The longest diameter of model ice particles is $3.5 \mathrm{~mm}$ long. The model bridge piers which are cylindrical and installed in the center of the flume at CS-16 have diameters of $D=2 \mathrm{~cm}$, $D=3 \mathrm{~cm}, D=4 \mathrm{~cm}$, respectively. Before each experimental run, the flow condition in the flume was adjusted by changing the flow rate and the tailgate. The rate of ice particles discharged from the ice hopper was adjusted and controlled.

According to the standard requirements of the People's Republic of China (MTPRC, 2004), the bridge pier diameter should be less than $0.8 \mathrm{~m}$ when the bridge span is in the range of $5-20 \mathrm{~m}$, namely, the pier-to-span radio $(\mathrm{d} / \mathrm{B})$ ranges from 0.04 to 0.16 . Also, a lot of researchers did numerical simulations and experimental studies on local scour around cylindrical piers under open flow conditions (Jiang et al., 1994; Ling et al., 2007; Wei et al., 2015; Zhu and Liu, 2011). Existing research works showed that the $\mathrm{D} / \mathrm{B}$ ranges from 0.04 to 0.11 . In the present study, the ratio of bridge pier diameter $(D=2 \mathrm{~cm})$ to the width of the laboratory flume $(B=40 \mathrm{~cm})$ is 0.05 , which is reasonable.

Cross section CS-5 was used as the control cross section. The approaching water depth $\left(H_{0}\right)$ and the initial average flow velocity $\left(V_{0}\right)$ at CS-5 are used as the initial hydraulic condition. At each cross section between CS-5 and CS-20, piezometers were installed to monitor the variation in water level. During each experimental run, measurements of water level, ice jam thickness and length of scour hole around the pier were recorded. The maximum scour depth was measured at the end of each experimental run. Experiments showed that after about 6 hours, no significant changes in the scour depth and jam thickness, and the quasi-equilibrium depth of scour hole and thickness of ice jam achieved. However, all experiment runs lasted 24 hours to ensure that the local scour process and ice jam accumulation around the bridge pier reach equilibrium. Under such an equilibrium condition, the shape of the deposition dune doesn't change since the scour process at the pier stops completely. Additionally, the ice jam thickness doesn't change. In total, 45 experiments have been conducted under different flow conditions (flow depth, flow velocity) and cover conditions (open flow, sheet ice cover, and ice jam), as showed in Table 1.

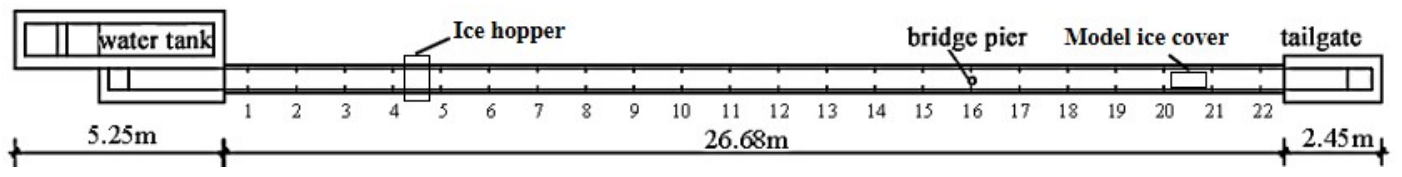

Fig. 1. Flume for experiment of local scour under ice jammed condition. 
Local scour around a bridge pier under ice-jammed flow condition - an experimental study

Table 1. Flow conditions for each experimental run.

\begin{tabular}{|c|c|c|c|c|c|c|c|c|c|}
\hline Number & $\begin{array}{c}\text { Average ap- } \\
\text { proaching flow } \\
\text { velocity } \\
V_{0}\left(\mathrm{~m} \cdot \mathrm{s}^{-1}\right)\end{array}$ & $\begin{array}{l}\text { Approaching } \\
\text { flow depth } H_{0} \\
\text { (m) }\end{array}$ & $\begin{array}{c}\text { Pier } \\
\text { diameter } \\
D(\mathrm{~m})\end{array}$ & $\begin{array}{c}\text { Grain } \\
\text { size of } \\
\text { sand bed } \\
d_{50}(\mathrm{~mm})\end{array}$ & Number & $\begin{array}{c}\text { Average ap- } \\
\text { proaching flow } \\
\text { velocity } \\
V_{0}\left(\mathrm{~m} \cdot \mathrm{s}^{-1}\right)\end{array}$ & $\begin{array}{l}\text { Approaching } \\
\text { flow depth } H_{0} \\
\text { (m) }\end{array}$ & $\begin{array}{c}\text { Pier } \\
\text { diameter } \\
D(\mathrm{~m})\end{array}$ & $\begin{array}{c}\text { Grain } \\
\text { size of } \\
\text { sand bed } \\
d_{50}(\mathrm{~mm})\end{array}$ \\
\hline $\mathrm{A} 2$ & 0.18 & 0.20 & 0.02 & 0.714 & $\mathrm{C} 1$ & 0.16 & 0.20 & 0.02 & 0.714 \\
\hline A3 & 0.19 & 0.20 & 0.02 & 0.714 & $\mathrm{C} 2$ & 0.17 & 0.20 & 0.02 & 0.714 \\
\hline A4 & 0.20 & 0.20 & 0.02 & 0.714 & $\mathrm{C} 3$ & 0.18 & 0.20 & 0.02 & 0.714 \\
\hline A6 & 0.18 & 0.25 & 0.02 & 0.714 & $\mathrm{C} 5$ & 0.20 & 0.20 & 0.02 & 0.714 \\
\hline A7 & 0.19 & 0.25 & 0.02 & 0.714 & C6 & 0.16 & 0.25 & 0.02 & 0.714 \\
\hline A8 & 0.20 & 0.25 & 0.02 & 0.714 & $\mathrm{C} 7$ & 0.17 & 0.25 & 0.02 & 0.714 \\
\hline A9 & 0.17 & 0.30 & 0.02 & 0.714 & $\mathrm{C} 8$ & 0.18 & 0.25 & 0.02 & 0.714 \\
\hline A 10 & 0.18 & 0.30 & 0.02 & 0.714 & $\mathrm{C} 9$ & 0.19 & 0.25 & 0.02 & 0.714 \\
\hline A11 & 0.19 & 0.30 & 0.02 & 0.714 & $\mathrm{C} 10$ & 0.20 & 0.25 & 0.02 & 0.714 \\
\hline $\mathrm{B} 1$ & 0.17 & 0.20 & 0.02 & 0.714 & $\mathrm{C} 12$ & 0.17 & 0.30 & 0.02 & 0.714 \\
\hline $\mathrm{B} 2$ & 0.18 & 0.20 & 0.02 & 0.714 & $\mathrm{C} 13$ & 0.18 & 0.30 & 0.02 & 0.714 \\
\hline B3 & 0.19 & 0.20 & 0.02 & 0.714 & $\mathrm{C} 14$ & 0.19 & 0.30 & 0.02 & 0.714 \\
\hline B4 & 0.20 & 0.20 & 0.02 & 0.714 & $\mathrm{C} 15$ & 0.20 & 0.30 & 0.02 & 0.714 \\
\hline B5 & 0.17 & 0.25 & 0.02 & 0.714 & $\mathrm{C} 16$ & 0.16 & 0.25 & 0.03 & 0.714 \\
\hline B6 & 0.18 & 0.25 & 0.02 & 0.714 & $\mathrm{C} 17$ & 0.18 & 0.25 & 0.03 & 0.714 \\
\hline B7 & 0.19 & 0.25 & 0.02 & 0.714 & $\mathrm{C} 18$ & 0.20 & 0.25 & 0.03 & 0.714 \\
\hline B8 & 0.20 & 0.25 & 0.02 & 0.714 & $\mathrm{C} 19$ & 0.16 & 0.25 & 0.04 & 0.714 \\
\hline B9 & 0.17 & 0.30 & 0.02 & 0.714 & $\mathrm{C} 20$ & 0.18 & 0.25 & 0.04 & 0.714 \\
\hline B10 & 0.18 & 0.30 & 0.02 & 0.714 & $\mathrm{C} 21$ & 0.20 & 0.25 & 0.04 & 0.714 \\
\hline B11 & 0.19 & 0.30 & 0.02 & 0.714 & & & & & \\
\hline
\end{tabular}

\section{OBSERVATIONS OF EXPERIMENTAL RUNS}

The local scour processes around a bridge pier under the open flow condition are clearly different from those occurring under the sheet ice-covered flow condition. But in the experiment, it should be noted that the sheet ice cover normally floats on the water surface and remains stationary. By contrast, under the ice-jammed conditions, both the scour hole and ice jam deform simultaneously. Since the thickness of ice jam has significant impact on the deformation of scour hole (Wang et al., 2016; Wang et al., 2018), the local scour around bridge piers under the ice-jammed flow condition is inevitably more complex than that occurring under the sheet ice-covered flow condition. Based on the scour hole around the bridge pier under an ice-jammed flow condition, the development of the ice jam can be divided into 3 stages. As observed that all experimental runs showed the same characteristics in the scour process and ice accumulation around bridge piers. To clearly illustrate the development of an ice jam and the local scour process around a bridge pier, one experimental case is used to explain the scour process and ice accumulation around a bridge pier. This case has the initial approaching flow depth of $H_{0}=25 \mathrm{~cm}$ and the initial average approaching flow velocity of $V_{0}=18 \mathrm{~cm} / \mathrm{s}$.

During the initial development of an ice jam, the discharged ice particles from the ice-hopper are transported downstream, and an initial ice jam starts to form at the downstream cross section CS-21. With the continuously incoming ice particles from upstream, the initial ice jam progresses from the downstream cross section CS-21 to upstream. Experiments showed that the initial ice jam has approximately the same thickness along the entire flume. Before the initial ice jam approaches the bridge pier, all model ice particles that floating on water surface pass around the bridge pier, and water flow in front of the initial ice jam remains free surface. As the initial ice jam pro- gresses upstream, water level increases simultaneously along the entire flume. In the first stage, experiments show that the water level near the pier approaches to be constant value after an increase of about $0.5 \mathrm{~cm}$ (comparing to the initial water level under the open flow condition). Also, before the initial ice jam approaches the bridge pier, due to the local scour process in front of the bridge pier, the water level increases gradually. With the development of an initial ice jam, both the depth and width of the scour hole increase gradually. The development of a scour hole starts from the front face of the bridge pier, extends on both the left and right sides, eventually reaching the rear side of the bridge pier. This scouring process develops slowly. After about 30 minutes, the initial ice jam nearly approaches the bridge pier (say, before the bridge pier is surrounded by the initial ice jam). During this period, due to the increase in water depth caused by the initial ice jam, the local scour process around the bridge pier gradually weakens. Namely, the rate of development of the scour hole around the bridge pier is reduced. Results showed that, before the bridge pier is surrounded by the initial ice jam, both the depth and width of the scour hole are less than those under an open flow condition with the same initial flow condition (flow depth and velocity), as indicated in Table 2.

As the ice jam arrives at the bridge pier, local scour around the bridge pier intensifies. After the ice jam moves beyond the bridge pier, the scour hole near the pier clearly develops more quickly than it did before the ice jam reached the pier. During the development period of an initial ice jam, local scour process around a bridge pier is similar to that under a sheet ice-covered flow condition, since the thickness of the ice jam along the entire flume is approximately constant. After about 90 minutes or so, the head of the initial ice jam has reached to CS-5. As shown in Tables 2 and 3, one can see the differences in scour depth and water level before and after the initial ice jam passes 
the pier, compared to that under an open flow condition. Results showed that, after the ice jam passes the bridge pier, the depth of the scour hole is increased to a depth which is the same as the maximum scour depth under an open flow condition with the same initial flow condition (flow depth and velocity). Also, the length of the scour hole under the initial ice-jammed flow condition exceeds that under an open flow condition with the same initial flow condition. As indicated in Table 3, during the development of an initial ice jam, the water level increased significantly comparing to that under an open flow condition with the same initial flow condition. Thus, the presence of an ice jam clearly induces increases in the scour depth, scour length and water level.

After the development of an initial ice jam (which has approximately the same thickness along the entire flume) along the entire flume, then enters the thickening process of an ice jam accompanied by the ice-particle wave migration. The incoming ice particles from the ice hopper will be submerged and entrained by the flowing water. These submerged ice particles accumulate under the head of the initial ice jam. Thus, the head of the initial ice jam will become progressively thicker. During this thickening process, the flow cross-sectional area naturally decreases and the velocity of flowing water correspondingly increases. Thus, more of the ice particles accumulated under the head of ice jam will be eroded and transported downstream. Over time, the initial ice jam will be thickened from upstream to downstream. This will cause an increase in water level from upstream to downstream. Interestingly, the underside surface of ice jams has been gradually developed as an undulating or wavy surface, similar to the migrating sand or bed deposits during sediment transport. This undulating surface of the underside surface of an ice jam is defined as the "ice-particle migrating wave" (termed as the "ice particle wave" in this study).

Due to the presence of this ice particle wave, the thickness of an ice jam consequently varies. Experiments show that this "ice-particle wave" phenomenon affects the local scour around the bridge pier. Results indicate that when the thickness of an ice jam around the pier increases (wave crest), local scour intensifies; when the thickness of an ice jam around the bridge pier decreases (wave trough), the local scour is moderated. When the thickness of an initial ice jam is about $5 \mathrm{~cm}$, due to the accumulation of ice particles, the equilibrium thickness of an ice jam at the same cross section often increases to about double, or about $10 \mathrm{~cm}$. However, the maximum jam thickness (at the crest of an "ice-particle wave") can reach to $14 \mathrm{~cm}$. Note though that the thickness of an ice jam decreases along the flume from upstream to downstream. During the downstream migration process of an "ice-particle wave", the jam thickness also increases. The local scour process around the bridge pier also increase correspondingly. When the crest of an "iceparticle wave" approaches/passes the bridge pier, the local scour process around the bridge pier is obviously intensified. Many sediment particles are eroded from the scour hole and transported to the downstream side of the bridge pier. After about 4 hours (240 minutes) in the experiment, quite a few iceparticle waves had migrated downstream and passed the bridge pier. Both the depth and length of scour holes around the bridge pier further increased to values much greater than those occurring under open flow conditions, as summarized in Table 4.

As shown in Figure 2, an ice-particle wave migrates at cross section CS-16. At the crest of the ice-particle wave, the jam thickness is obviously greater than that before the ice wave migrates downstream. The flow depth at CS-16 (where the crest of the ice-particle wave is located) decreases, and thus the flow velocity increases. During the migration of an ice-particle wave, an intensified local scour process around the bridge pier at CS-16 will result. Clearly, the propagation of ice-particle waves plays is a key factor in the evolution of the channel bed around the bridge pier.

To be more specific, a coordinate system was established at CS-16. The origin of the coordinate system is located at the center of the bridge pier. Flow direction is opposite to the abscissa direction (X-axis). The $\mathrm{Y}$-axis is perpendicular to flow direction from the left flume wall to the right flume wall. The direction of the vertical axis (Z-axis) is upward. Figures 3a and $3 \mathrm{~b}$ show the contour lines of scour holes around the bridge pier after the local scour process achieves an equilibrium condition under both open flow and ice-jammed flow conditions, respectively. Figures $4 \mathrm{a}$ and $4 \mathrm{~b}$ are $3 \mathrm{D}$ illustrations of the scour holes at equilibrium under both open flow and ice-jammed conditions, respectively. The dotted lines in the contour maps represent the scour hole whereas solid lines indicate the deposition mound downstream of the pier.

As the scour patterns around bridge piers in Figures $3 \mathrm{a}$ to $4 \mathrm{~b}$ show, all scour holes are approximately symmetrically distributed along the centerline of flume passing the center of the bridge pier. The maximum scour depths are located at the front face of the bridge pier (facing flow). Under an ice-jammed flow

Table 2. Comparison of the depth and length of scour hole and water level (30 minutes after experiment started, initial flow condition: $\left.H_{0}=25 \mathrm{~cm}, V_{0}=0.18 \mathrm{~m} / \mathrm{s}\right)$.

\begin{tabular}{lccc}
\hline & Scour depth $(\mathrm{cm})$ & Scour length $(\mathrm{cm})$ & Water level $(\mathrm{cm})$ \\
\hline Initial ice-jam nearly approaches the pier & 0.3 & 4.9 & 35.3 \\
Open flow condition & 1.2 & 6.5 & 25.2 \\
\hline
\end{tabular}

Table 3. Comparison of the depth and length of scour hole and water level (90 minutes after experiment started, initial flow condition: $H_{0}=25 \mathrm{~cm}, V_{0}=0.18 \mathrm{~m} / \mathrm{s}$ ).

\begin{tabular}{lccc}
\hline & Scour depth $(\mathrm{cm})$ & Scour length $(\mathrm{cm})$ & Water level $(\mathrm{cm})$ \\
\hline Initial ice-jam passes the pier & 1.2 & 7.2 & 35.3 \\
Open flow condition & 1.2 & 6.5 & 25.2 \\
\hline
\end{tabular}

Table 4. Comparison of the depth and length of scour hole and water level (240 minutes after experiment started, initial flow condition: $\left.H_{0}=25 \mathrm{~cm}, V_{0}=0.18 \mathrm{~m} / \mathrm{s}\right)$.

\begin{tabular}{lccc}
\hline & Scour depth $(\mathrm{cm})$ & Scour length $(\mathrm{cm})$ & Water level $(\mathrm{cm})$ \\
\hline Ice-jammed flow condition & 2.2 & 10.5 & 35.5 \\
Open flow condition & 1.2 & 6.5 & 25.2 \\
\hline
\end{tabular}



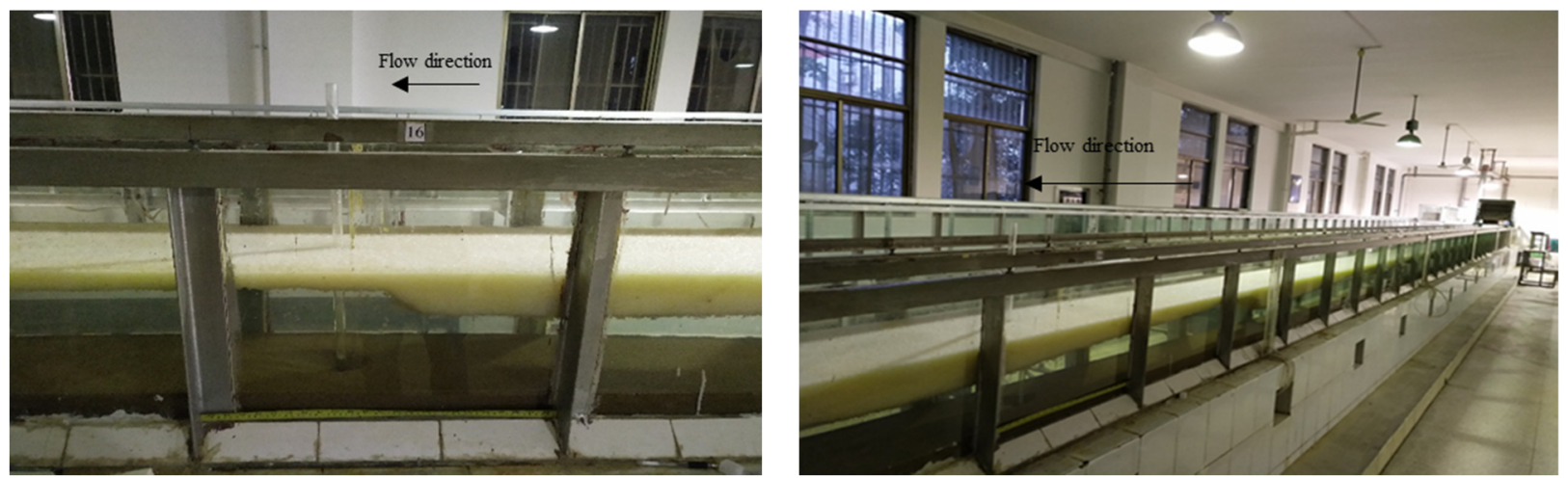

Fig. 2. Migration of an ice-particle wave around CS-16.
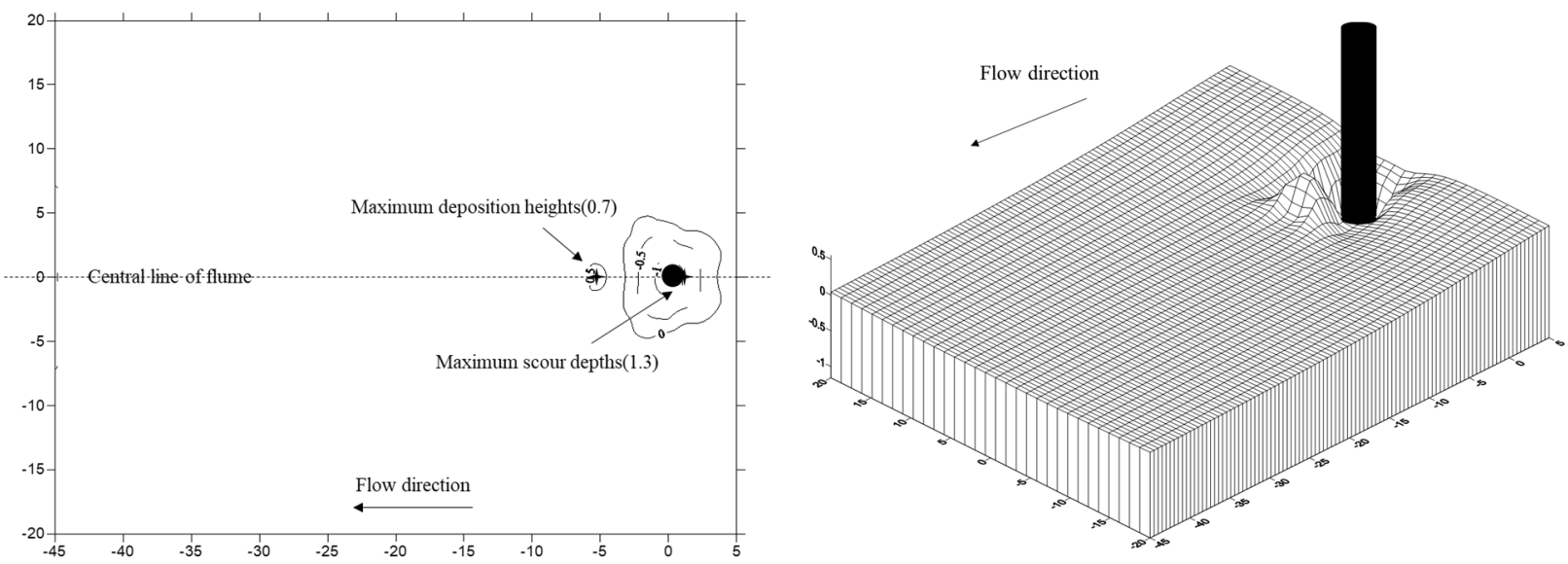

Fig. 3a. Contour lines for scour hole and deposition mound around the bridge pier under an open flow condition (unit: $\mathrm{cm}$ ).
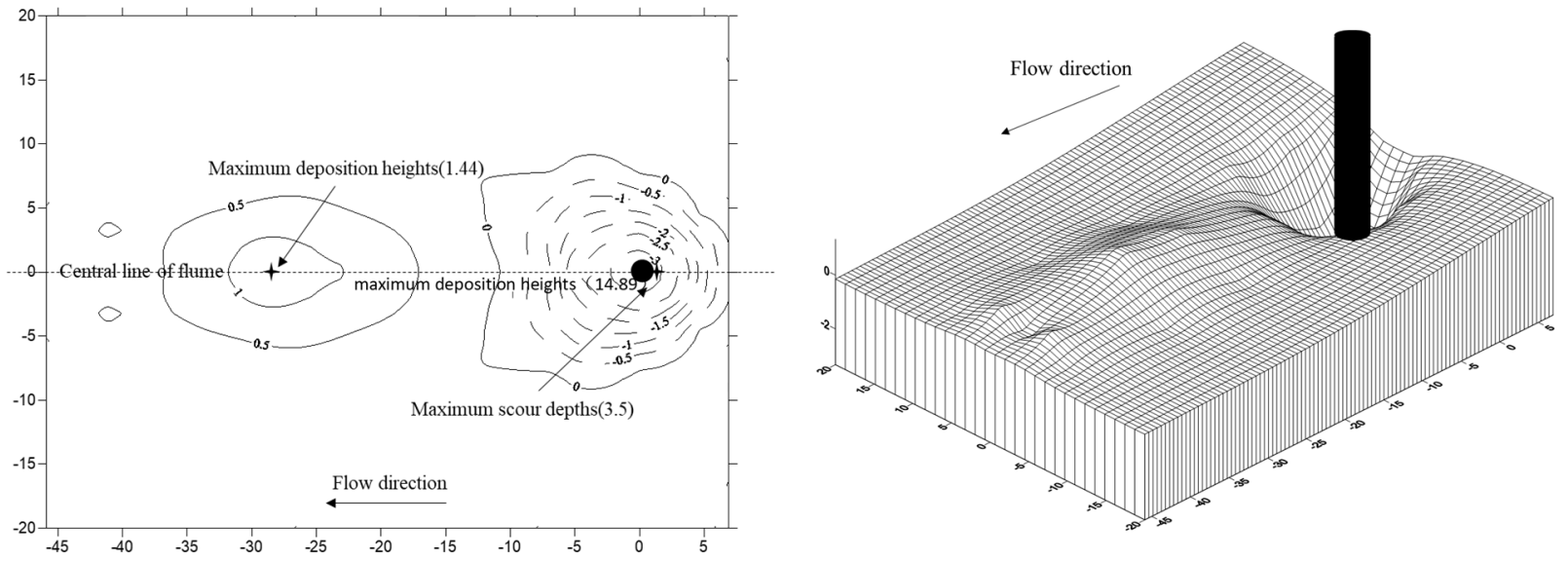

Fig. 3b. Contour lines for scour hole and deposition mound around the bridge pier under an ice-jammed flow condition (unit: $\mathrm{cm}$ ).

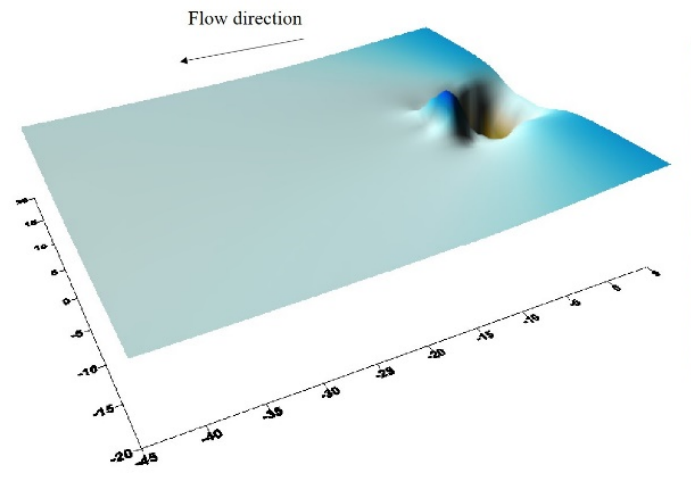

Fig. 4a. The 3D illustration for a scour hole and deposition mound around the bridge pier under the open flow condition (unit: $\mathrm{cm}$ ).

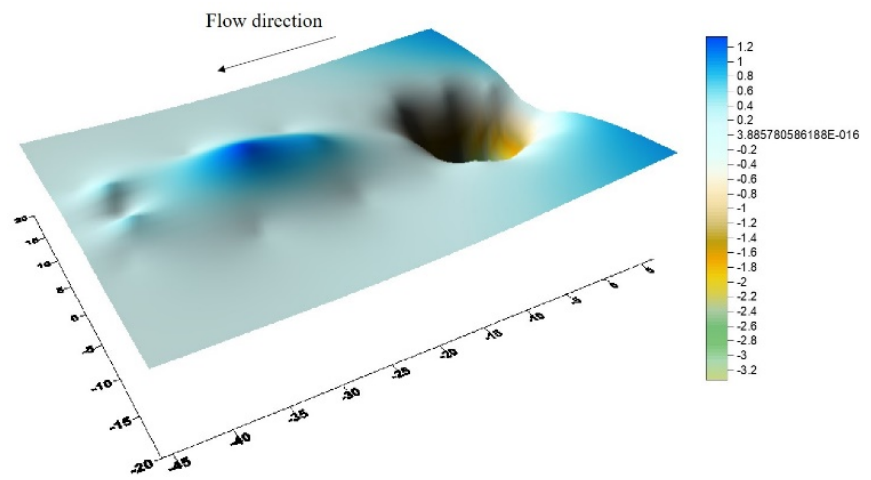

Fig. 4b. The 3D illustration for a scour hole and deposition mound around the bridge pier under an ice-jammed flow condition (unit: $\mathrm{cm}$ ). 
condition, both the maximum depth and the maximum length of scour holes exceed those under an open flow condition with the same initial flow condition. Also, patterns of the downstream deposition dune under an ice-jammed condition differ from that under an open flow condition. An intuitive comparison of scour hole profiles under different flow conditions is given in Figure 5. Obviously, both the maximum depth and the maximum length of scour holes under an ice-jammed condition are greater. Interestingly, the slope of the deposition dune downstream of the bridge pier under an ice jammed flow condition is considerably gentler and extended further downstream than those under an open flow condition. As indicated in Table 5, under an ice-jammed flow condition, the maximum scour depth of 3.5 $\mathrm{cm}$ is much more than that of $1.7 \mathrm{~cm}$ under an open flow condition. Also, the maximum length of the deposition dune under an ice-jammed flow condition is $17.45 \mathrm{~cm}$ which exceeds that under an open flow condition. The height of the deposition dune under an ice jammed flow condition is $1.44 \mathrm{~cm}$, which is about twice of that under an open flow condition.

Experiments showed that the development of scour holes under the initial ice-jammed condition differs from that under the thickening process of an ice jam. Also, before an initial ice jam approaches the bridge pier from downstream, the local scour processes around the bridge pier differs from that after the initial ice jam passes the bridge pier. Under conditions of both open flow and the initial ice jam, the local scour process starts at the front face of the bridge pier. The scour hole gradually becomes deeper and wider. After an initial ice jam passes the bridge pier, the local scour process at the pier is similar to that under a sheet ice-covered flow condition, since the thickness of the initial ice jam doesn't change much. During the ice jam thickening (or ice-particle wave migration) process, the thickness of the ice jam varies. Whenever the crest of an "iceparticle wave" passes the cross section where the bridge pier is located, the cross-sectional area for flow decreases, and the flow velocity around the scour hole is clearly increased. Thus, the local scour around the bridge pier is strengthened when the crest of an "ice-particle wave" passes the bridge pier. Sediment particles are rapidly eroded and transported downstream. Whenever the trough of an ice-particle wave passes the cross section where the bridge pier is located, the flow depth under the ice jam is increased. Thus, flow velocity around the scour hole decreases, and the local scour around the bridge pier is weakened. Overall, once initiated, the downstream propagation of the ice-particle waves continued throughout each experimental run. The alternation from the crest of "ice-particle wave" to the trough of "ice-particle wave" was continually repeated. Correspondingly, the alternation of the local scour process continues from the intensified scour process to the weakened scour process, until the local scour process reached an equilibrium condition.

\section{RESULTS}

Under an open flow condition, without a deformation of channel bed, the flow field around the bridge pier is highly complex. With the development of a scour hole around the bridge pier and a deposition dune downstream of the bridge pier, the flow field becomes even more complicated. According to Hafez (2016), the scour commences in the region of the highest velocity in the vicinity of the separating streamline. The horseshoe vortex which forms at the pier face shifts the maximum downflow velocity closer to the pier in the scour hole. The downflow acts as a vertical jet to erode a groove in front of the pier. The eroded sand particles are carried around the pier by the combined action of an accelerating flow and the spiral motion of the horseshoe vortex. Melville and Coleman (2000) report a wake-vortex system which occurs behind the pier, acts like a vacuum hose sucking up bed material and transporting sand particles moved by the horseshoe vortex system and by the downward flow to locations downstream of the pier. However, wake-vortices are not normally as strong as the horseshoe vortex and therefore, are not able to carry as great a sediment load as the horseshoe vortex. Therefore, sediment deposition is likely to occur downstream of the pier in the form of a sediment deposition dune.

Table 5. The maximum depth and length of scour hole and height of deposition dune (Equilibrium ice jammed condition, initial flow condition: $H_{0}=25 \mathrm{~cm}, V_{0}=0.18 \mathrm{~m} / \mathrm{s}$ ).

\begin{tabular}{lccc}
\hline & Scour depth $(\mathrm{cm})$ & Scour length $(\mathrm{cm})$ & Height of deposition dune $(\mathrm{cm})$ \\
\hline Condition of equilibrium ice jam & 3.5 & 17.45 & 1.44 \\
Open flow condition & 1.3 & 7.15 & 0.70 \\
\hline
\end{tabular}

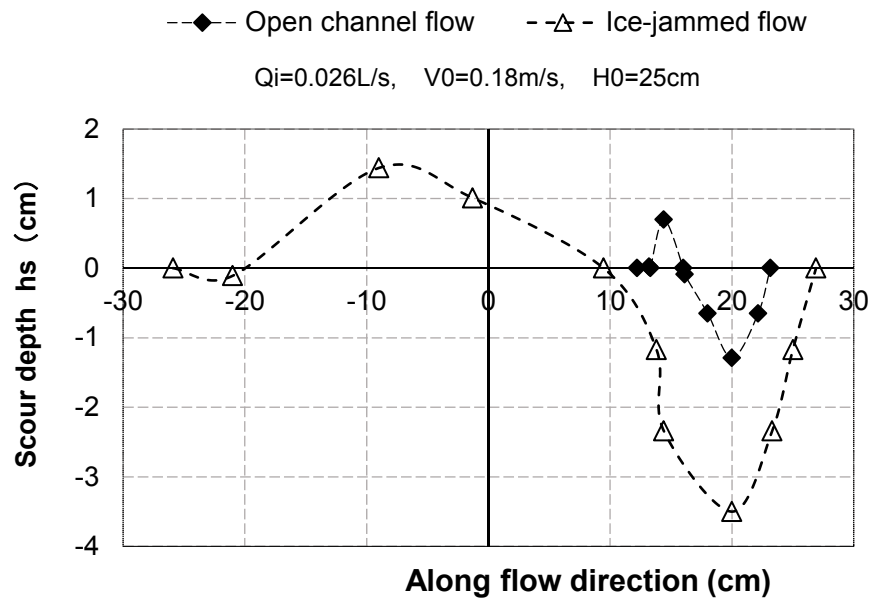

Note: Flow direction to the left

Fig. 5. Profiles of scour hole the under open flow and ice-jammed conditions. 
When an ice cover or ice jam is present, the velocity profile is significantly modified. Quite naturally, the location of the maximum velocity is now intermediate between the channel bed and ice cover, with a specific location that depends on the ratio of the cover roughness to the bed roughness (Sui et al., 2010). As a result, the local scour process is modified as well.

\section{Depth of scour hole}

The comparison of the maximum depths of scour holes under the open flow, sheet ice-covered flow and ice-jammed flow conditions are given in Figures $6 \mathrm{a}$ and $6 \mathrm{~b}$ for different initial approaching flow depths of $25 \mathrm{~cm}$ and $30 \mathrm{~cm}$, respectively. The following summary observation can be drawn: With the same initial flow condition (same initial approaching flow depth and flow velocity), the maximum scour depth under a sheet icecovered flow condition is greater (about 13\% more) than that under a free surface condition. This finding is different from results reported by other researchers as mentioned above (Ackermann et al., 2002; Munteanu, 2004). Although results obtained different researchers are different due to the different laboratory setups, all results indicate that an ice sheet intensifies the local scour at the pier.

However, under an ice-jammed flow condition, the maximum scour depth is much more (or over $200 \%$ more) than that under an open flow condition. Clearly, the impact of an ice jam on the local scour around the bridge pier is much more than of a sheet ice-cover.

When the initial approaching flow velocity is low, the maximum scour depth under an ice-jammed flow condition is much greater (200 to $400 \%$ ) than that under an open flow condition. By contrast, when the initial approaching flow velocity is high, the maximum scour depth under an ice-jammed flow condition is about twice than that under an open flow condition, which is itself much greater than that under both sheet ice-covered flow and open flow conditions.

Regardless of flow cover conditions (open flow, sheet icecovered flow and ice-jammed flow), the maximum scour depth increases with the flow velocity. Interestingly, under an icejammed flow condition, the maximum scour depth shows a gentler increase with velocity comparing to that under both open flow and sheet ice-covered flow conditions.

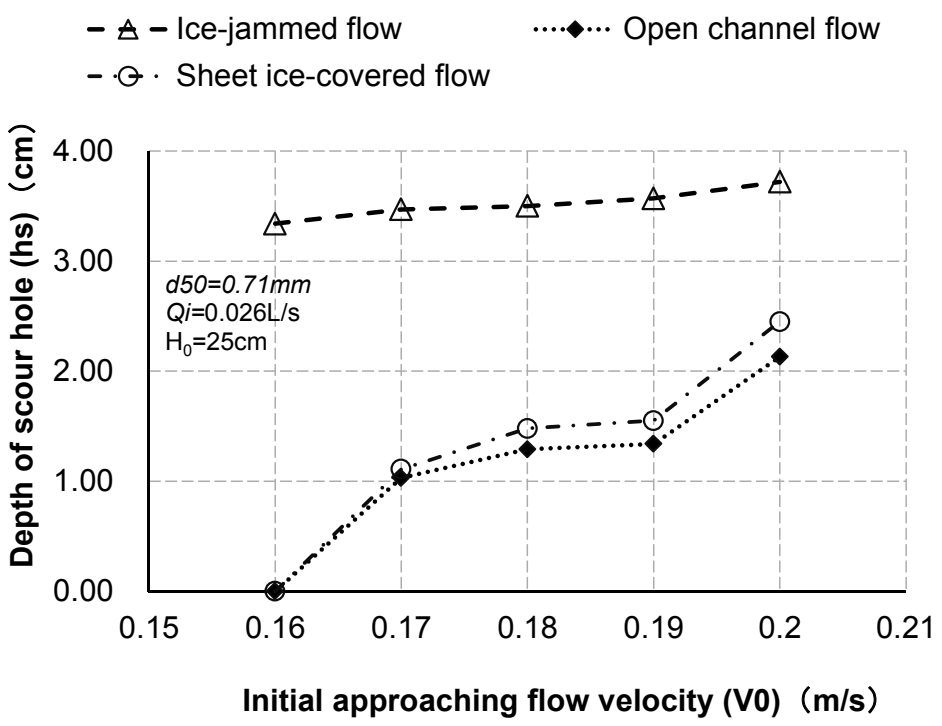

Fig. 6a. The maximum scour depth vs. the initial approaching flow velocity (initial approaching flow depth: $H_{0}=25 \mathrm{~cm}$ ).

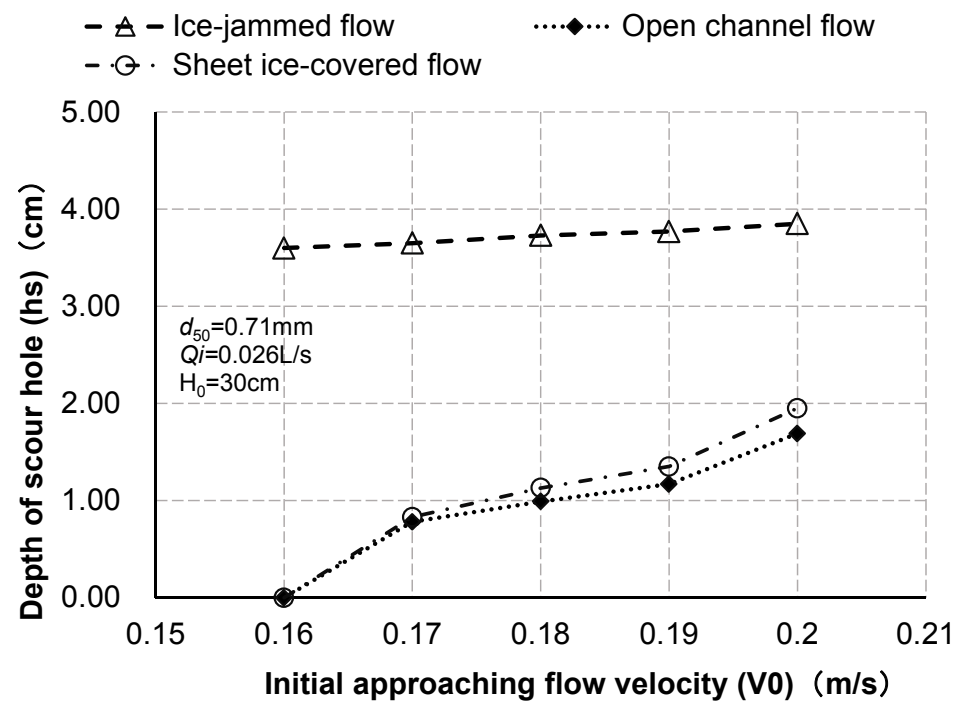

Fig. 6b. The maximum scour depth vs. the initial approaching flow velocity (initial approaching flow depth: $H_{0}=30 \mathrm{~cm}$ ). 
Results showed that, when the initial approaching flow depth is shallow, changes in the flow velocity will dramatically affect the maximum scour depth under an ice-jammed flow condition.

Figure 7 gives the dependence of the dimensionless maximum scour depth $(\mathrm{hs} / \mathrm{H})$ on the flow Froude Number $(\mathrm{Fr}=$ $\mathrm{V} /(\mathrm{gH})^{0.5}$, where, $\mathrm{V}=$ average flow velocity, $\mathrm{g}=$ gravitational acceleration, and $\mathrm{H}=$ water depth). Under an ice-jammed flow condition, the data sets are clearly above those under both open flow and sheet ice-covered flow conditions.

Overall (regardless flow cover condition):

$\frac{h_{s}}{H}=2.439 \frac{V}{\sqrt{g H}}-0.227 \quad$ with $\mathrm{R}^{2}=0.950$

Under an ice-jammed flow condition:

$\frac{h_{s}}{H}=2.014 \frac{V}{\sqrt{g H}}-0.146 \quad$ with $\mathrm{R}^{2}=0.951$

Clearly, regardless of flow cover conditions, the dimensionless maximum scour depth increases with the flow Froude Number, as showed in Equations (1) and (2).

Figure 8 shows the relationship between the dimensionless maximum scour depth $(\mathrm{hs} / \mathrm{H})$ and the dimensionless thickness of ice jam $(\mathrm{Ti} / \mathrm{H})$. One can see that the thicker an ice jam, the deeper the maximum depth of a scour around the pier. Namely, a thicker ice jam can lead to a deeper scour hole around a bridge pier. This explains why the local scour process is intensified when the crest of an "ice-particle wave" passes the bridge pier, and why the local scour process is diminished when the trough of an "ice-particle wave" passes the bridge pier.

The size of bridge pier is also an important factor affecting the scour depth. Results showed that the larger the pier diameter, the deeper the maximum depth of scour hole around the pier. Figure 9 shows the relationship between the maximum scour depth $(\mathrm{hs} / \mathrm{H})$ and the pier size $(\mathrm{D} / \mathrm{H})$.

\section{Length of scour hole}

The length of scour hole is an indicator of the range of a local scour hole around a bridge pier. The comparison of the maximum lengths of scour holes under open flow, sheet icecovered flow and ice-jammed flow conditions are given in Figures $10 \mathrm{a}$ and $10 \mathrm{~b}$ for different initial approaching flow depths of $25 \mathrm{~cm}$ and $30 \mathrm{~cm}$, respectively. The following statements summarize these observations:

With the same initial flow condition (same initial approaching flow depth and flow velocity), the maximum scour length under a sheet ice-covered flow condition slightly exceeds (by about $5 \%$ ) that occurring under an open flow condition. However, under an ice-jammed flow condition, the maximum scour length tends to be much greater (even $110 \%$ more) than that under an open flow condition. Clearly, the impact of an ice jam on the local scour process greatly exceeds that of a sheet ice-cover.Regardless of flow cover conditions (open flow, sheet ice-covered and icejammed flow), the maximum scour length increases with the flow velocity. With the same initial flow condition, the maximum scour range under an ice-jammed flow condition is much larger than those under both open flow and sheet ice-covered flow conditions.

When the initial approaching flow depth is shallow, changes in flow velocity will dramatically affect the maximum scour length under an ice-jammed flow condition, comparing to that with a deep initial approaching flow depth.

Figure 11 gives the dependence of the dimensionless maximum scour length $(\mathrm{Ls} / \mathrm{H})$ on the flow Froude Number $(\mathrm{Fr})$. Clearly, regardless of flow cover conditions, the dimensionless maximum scour length increases with the flow Froude Number:

Overall (regardless flow cover condition):

$\frac{L_{s}}{H}=11.011 \frac{V}{\sqrt{g H}}-0.986$, with $\mathrm{R}^{2}=0.943$

Under an ice-jammed flow condition:

$\frac{L_{s}}{H}=11.67 \frac{V}{\sqrt{g H}}-1.074$, with $\mathrm{R}^{2}=0.912$

Under an ice-jammed flow condition, the observed data clearly lie above those under both open flow and sheet icecovered flow conditions.

\section{Dependence of maximum scour depth on Froude Number}

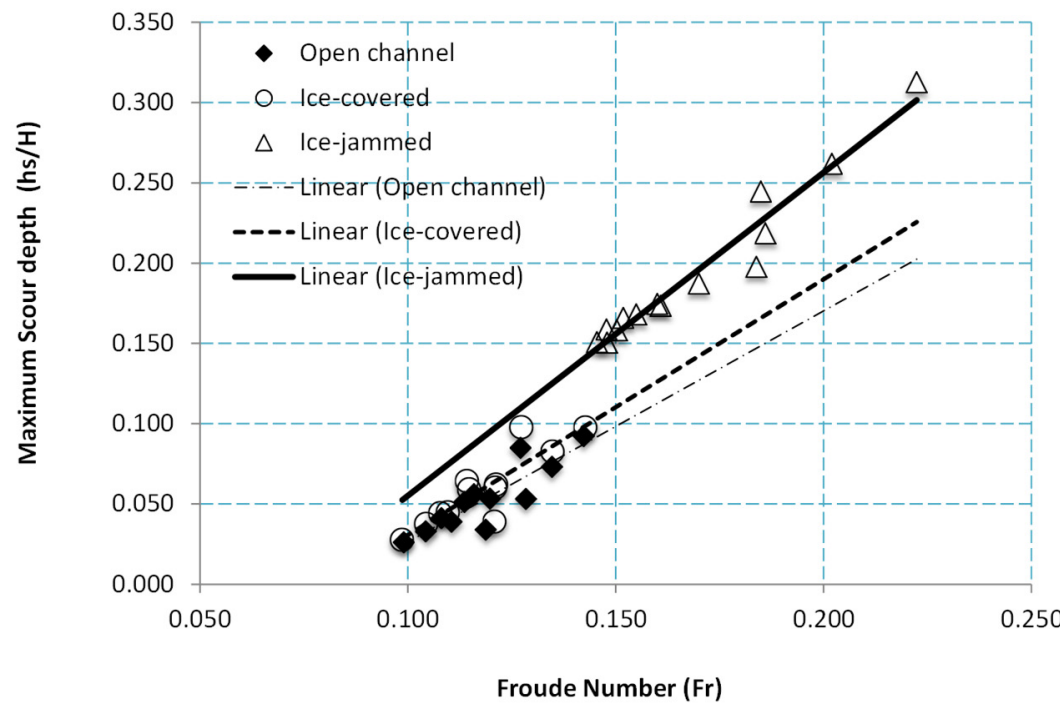

Fig. 7. Dependence of the maximum scour depth on the flow Froude Number. 
Relation between maximum scour depth and ice jam thickness

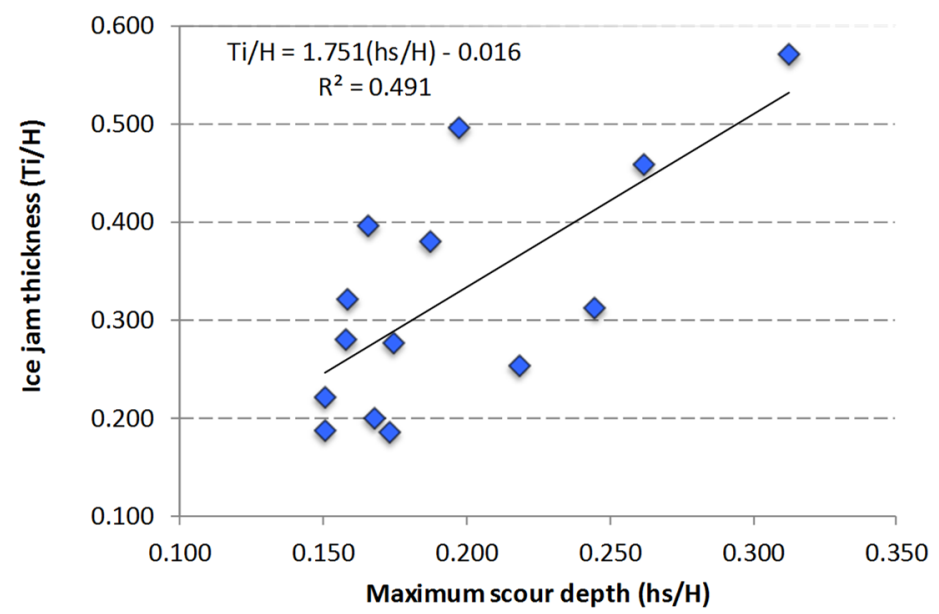

Fig. 8. Relationship between the maximum scour depth and the thickness of ice jam.

\section{Relation between the maximum scour depth and bridge}

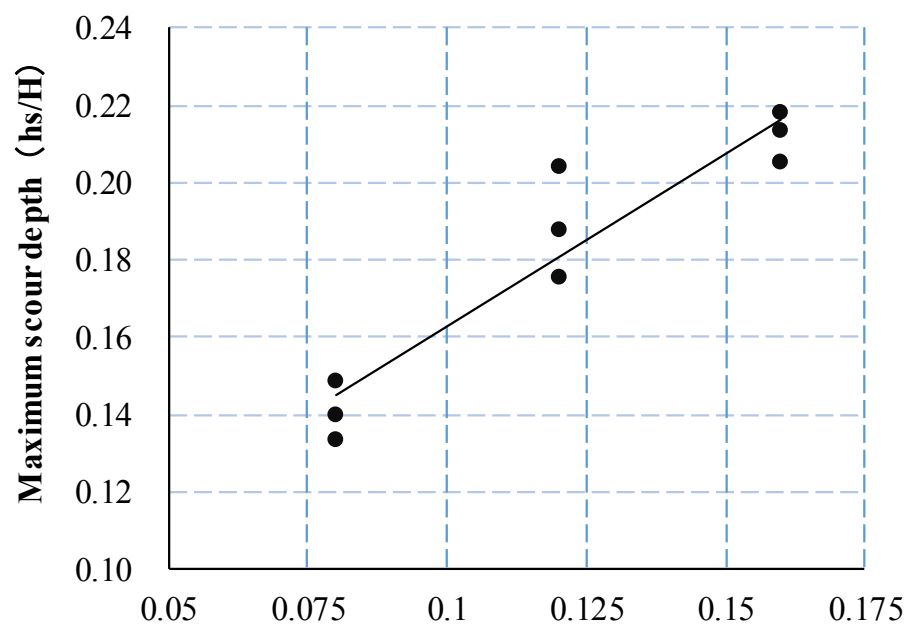

The bridge pier diameter $(\mathrm{D} / \mathrm{H})$

Fig. 9. Relationship between the maximum scour depth and the bridge pier diameter.

\section{Deposition dune}

Experiments show that, during a local scour process around the bridge pier, an associated deposition dune develops downstream of the pier. The features of a deposition dune (such as length, height and slope) under an open flow condition are different from those under both sheet ice-covered flow and icejammed flow conditions. The comparison of the maximum heights of deposition dunes under open flow, sheet ice-covered flow and ice-jammed flow conditions are given in Figure 12 for an initial approaching flow depth of $20 \mathrm{~cm}$. Following observations can be summarized:

With the same initial approaching flow depth, regardless of flow cover conditions, progressively more sediment is eroded from the scour hole and delivered downstream, thus forming the deposition dune. The higher the initial approaching flow velocity, the larger (thicker) will be the deposition dune.

Under varied cover conditions, different characteristics of the deposition dune will be evident. Under an ice-jammed flow condition, since flow velocity is increased, the thickness of an ice jam varies. This process affects the local scour process around the bridge pier, and thus, the pattern of a deposition dune. Namely, the impact of an ice jam on the pattern of a deposition dune is different from that under both sheet icecovered flow and open flow conditions. One can see from Figure 12, the height of a deposition dune under an ice-jammed flow condition increases gently with the initial approaching flow velocity. However, under both sheet ice-covered flow and open flow conditions, the height of deposition dunes increases rapidly with the initial approaching flow velocity.

Under an ice-jammed flow condition, with the same initial approaching flow depth, the thickness of an ice jam decreases with the increase in the flow velocity. As a consequence, with the increase in flow velocity, the wave height of the ice particle wave decreases. Thus, under a relatively high flow velocity, the impact of the migration process of an "ice particle wave" on the height of a deposition dune is diminished. Namely, the height of a deposition dune under an ice-jammed flow condition is less than that under both sheet ice-covered flow and open flow conditions.

Under an ice-jammed flow condition, much more sediment is eroded from the scour hole around the bridge pier and transported to downstream, compared to that under both sheet icecovered flow and open flow conditions. However, the slope of a deposition dune under an ice-jammed flow condition is much longer but milder than those under both sheet ice-covered flow and open flow conditions. 


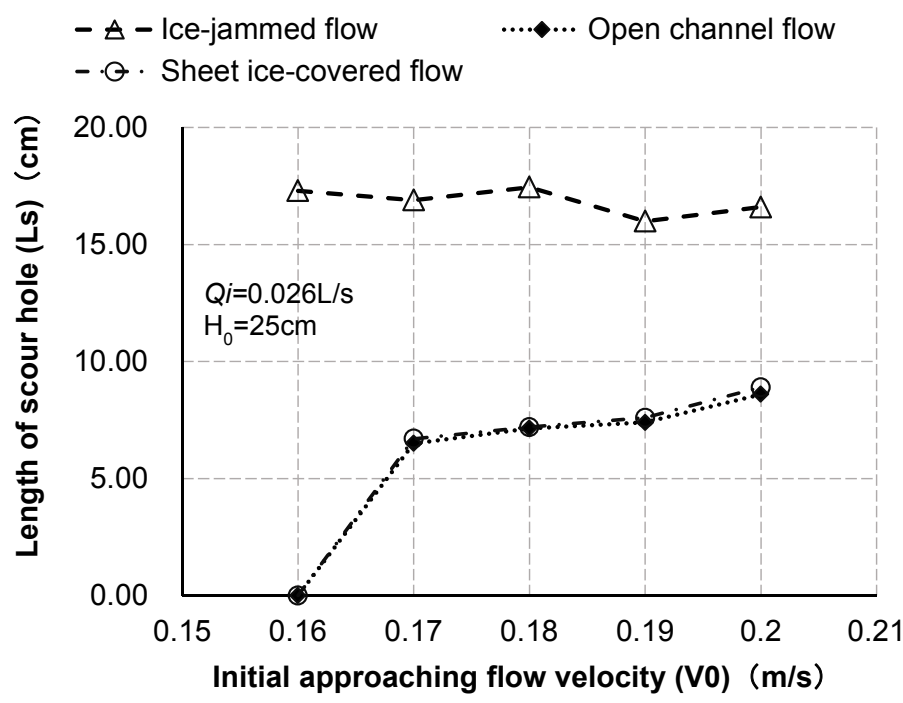

Fig. 10a. The maximum scour length vs. the initial approaching flow velocity (initial approaching flow depth: $H_{0}=25 \mathrm{~cm}$ ).

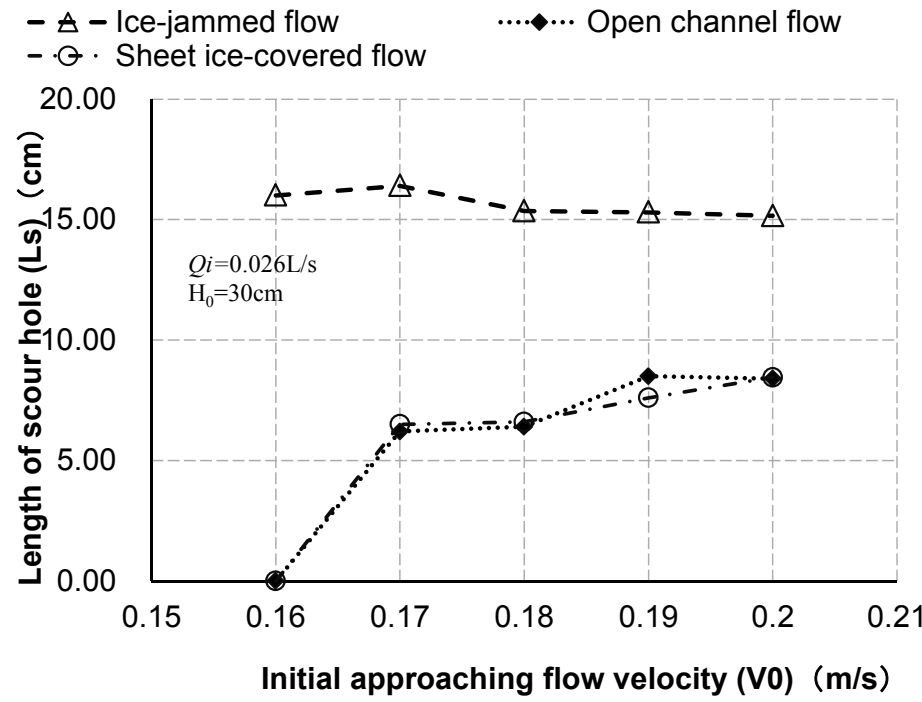

Fig. 10b. The maximum scour length vs. the initial approaching flow velocity (initial approaching flow depth: $H_{0}=30 \mathrm{~cm}$ ).

Dependence of maximum scour length on Froude Number

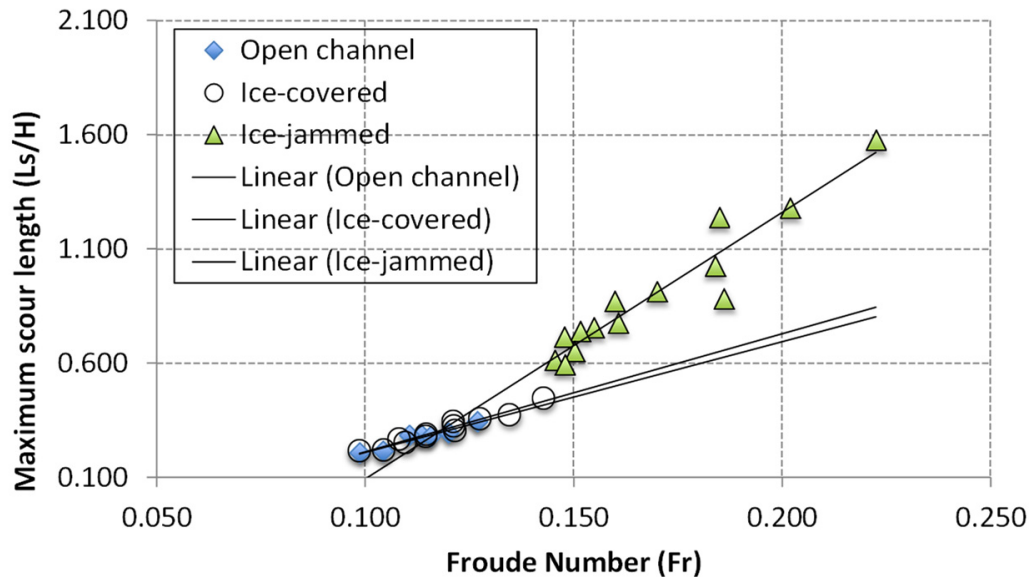

Fig. 11. Dependence of the maximum scour length on the flow Froude Number.

Results showed, regardless of flow cover conditions, the maximum height of deposition dune $(\mathrm{Ts} / \mathrm{H})$ increases with the flow Froude Number (Fr), as presented in Figure 13,

$$
\frac{T_{s}}{H}=0.108 \ln \left(\frac{V}{\sqrt{g H}}\right)+0.271 \text { with } \mathrm{R}^{2}=0.86
$$




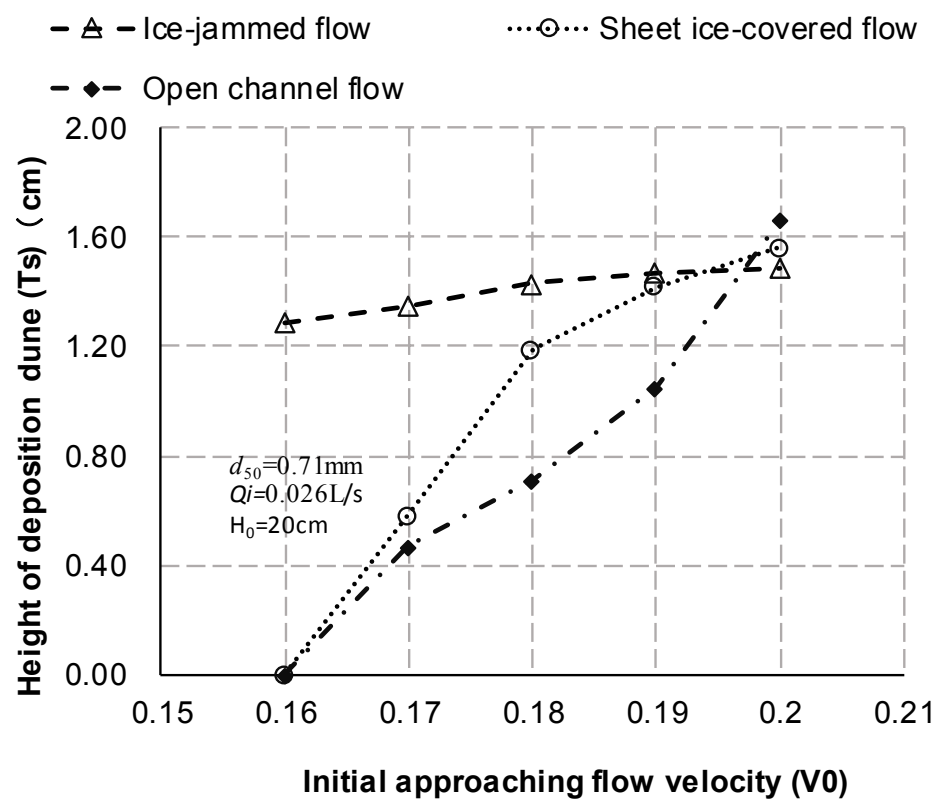

Fig. 12. The maximum height of deposition dune vs. the initial approaching flow velocity (initial approaching flow depth: $H_{0}=20 \mathrm{~cm}$ ).

Dependence of the height of deposition dune on Froude Number

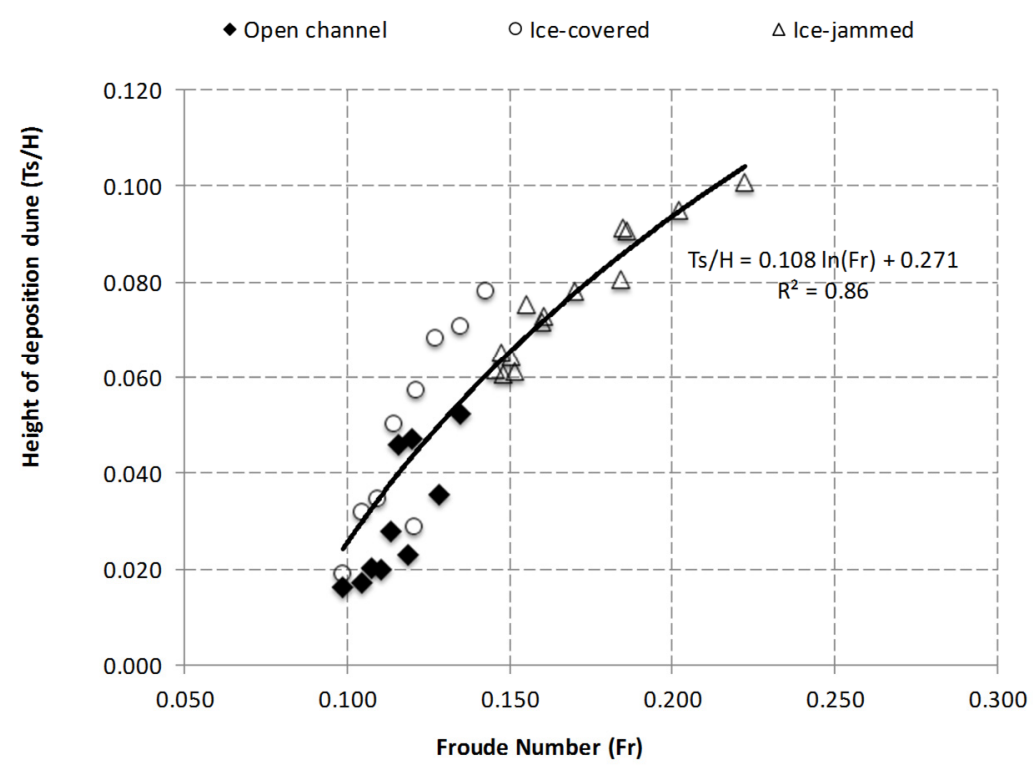

Fig. 13. Dependence of the maximum height of deposition dune $(\mathrm{Ts} / \mathrm{H})$ on the flow Froude Number $(\mathrm{Fr})$.

\section{CONCLUSIONS}

The present experimental research is only a conceptual study for providing engineering with some knowledge regarding the mechanism of local scour process at piers under an ice-jammed flow condition. The evolution process of ice jams in natural rivers is very complex. The coefficients of the proposed equations derived from data gained in laboratory experiments need to be further modified based on data collected in natural rivers. Based on both laboratory experiments and field investigations of ice jams in natural river, Sui et al. (1994) claimed that the evolution mechanism of model ice jam in laboratory is similar to that of ice jams in the Hequ Reach of the Yellow River. The purpose of this research work is to explore the complex mechanism of local scour around bridge piers under an ice-jammed flow condition. Laboratory experiments clarify the local scour process in the vicinity of a bridge pier under an ice-jammed flow condition. the following strong tendencies can be noted:

1). With the same initial flow condition, the maximum scour depth under a sheet ice-covered flow condition exceeds that under an open flow condition. However, under an icejammed flow condition, the maximum scour depth is much greater than that under an open flow condition.

2). When the initial approaching flow velocity is low, both the maximum scour depth and maximum length of scour hole under an ice-jammed flow condition are much greater than that under both sheet ice-covered flow and open flow conditions. Also, the range of the deposition dune under an icejammed flow condition is much larger, comparing to that under both sheet ice-covered flow and open flow conditions.

3). Both the maximum scour depth and scour length under an ice-jammed flow condition increases with the flow 
velocity. The dimensionless maximum scour depth increases with the flow Froude Number. Results show that the thicker the ice jam, the deeper the maximum depth of a scour hole around the bridge pier. One can say that a thicker ice jam will likely lead to a deeper scour hole around a bridge pier. When the crest of an ice-particle wave passes the bridge pier, the local scour process is intensified; but when the trough of this wave passes, the local scour process diminishes.

4). Under an ice-jammed flow condition, the impact of an ice jam on the pattern of a deposition dune is different from that under both sheet ice-covered flow and open flow conditions. With the same initial approaching flow depth, regardless of flow cover conditions, the higher the initial approaching flow velocity, the higher the deposition dune. The height of a deposition dune under an ice-jammed flow condition increases gently with the initial approaching flow velocity. However, under both sheet ice-covered flow and open flow conditions, the height of deposition dune increases rapidly with the initial approaching flow velocity. With the increase in flow velocity, the wave height of the ice particle wave decreases. Thus, under a relatively high flow velocity, the impact of the migration process of an ice particle wave on the height of a deposition dune is diminished. Also, the slope of the deposition dune under an ice-jammed flow condition is much longer but milder than that under both sheet ice-covered flow and open flow conditions. Regardless of flow cover conditions, the dimensionless maximum height of deposition dune increases with the flow Froude Number.

5). Most of the existing studies regarding local scour at piers are cylindrical piers. To our knowledge, the mechanisms regarding local scour around piers under an ice-jammed condition has never explored. The present research is the first one regarding this topic. In present study, only cylindrical piers with different pier diameters have been used. As reported by researchers (Günal et al., 2017; Tyminski, 2010), under the open flow conditions, the scour process around different pier types is different. The future research work will be focused on the local scour process by using different pier types and arrangement under an ice jammed condition.

Acknowledgement. This research is supported by the National Natural Science Foundation of China (Grant Nos. 51879065). The authors are grateful for the financial support.

\section{REFERENCES}

Abou-Seida, M.M., Elsaeed, G.H., Mostafa T.M., Elzahry, E.F., 2012. Local scour at bridge abutments in cohesive soil. Journal of Hydraulic Research, 50, 2, 171-180.

Ackermann, N.L., Shen, H.T., Olsson, P., 2002. Local scour around circular piers under ice covers. In: Proceedings of the 16th IAHR International Symposium on Ice in the Environment, Dunedin, New Zealand, 2nd Vol., pp. 149-155.

Alemi, M., Pêgo, J.P., Maia, R., 2019. Numerical simulation of the turbulent flow around a complex bridge pier on the scoured bed. European Journal of Mechanics /B Fluids, 76, 316-331.

Amini, A., Mohammad, T.A., 2016. Local scour prediction around piers with complex geometry. Marine Georesources \& Geotechnology, 35, 6, 857-864.

Batuca, D., Dargahi, B., 1986. Some experimental results on local scour around cylindrical piers for open and covered flow. In: Third International Symposium on River Sedimentation, University of Mississippi.

Beltaos, S., 1995. River Ice Jam. Water-Resources Publications,
LLC, Highlands Ranch, Colorado, U.S.A., pp.155-172.

Beltaos, S., 2012. Distributed function analysis of ice jam flood frequency. Cold Regions Science and Technology, 71, 2, $1-10$.

Buzin, V.A., Goroshkova, N.I., Strizhenok A.V., 2015. Maximum ice-jam water levels on the northern rivers of Russia under conditions of climate change and anthropogenic impact on the ice jamming process. Russian Meteorology \& Hydrology, 39, 12, 823-827.

Carr, M.L., Tuthill, M.A., 2012. Modeling of Scour-Inducing Ice Effects at Melvin Price Lock and Dam. Journal of Hydraulic Engineering, 138, 1, 85-92.

Günal, M., Gelmeran, T.A., Günal, A.Y., 2017. Local scour around group bridge pier with different shapes. Acta Physica Polonica Series a, 132, 3, 632-633.

Hafez, Y.I., 2016. Mathematical modeling of local scour at slender and wide bridge piers. Journal of Fluids, Article ID: 4835253. http://dx.doi.org/10.1155/2016/4835253

Hains, D.B., Zabilansky, L.J, 2004. Laboratory test of scour under ice: Data and preliminary results. U.S. Army Engineer Research and Development Center, Cold Regions Research and Engineering Laboratory, Hanover, New Hampshire, Technical Report TR-04-9 (http://www.crrel.usace.army.mil/techpub/CRREL_Reports/ reports/TRO4-9.pdf).

Healy, D., Hicks, F.E., 2007. Experimental study of ice jam thickening under dynamic flowconditions. Journal of Cold Regions Engineering, 21, 3, 72-91.

Hosseini, R., Amini, A., 2015. Scour depth estimation methods around pile groups. KSCE Journal of Civil Engineering, 19, 7, 2144-2156.

Jiang, H., 1994. Experimental study of local scour protection on bridge pier. Highway, 8, 1-8.

Khaple, S., Hanmaiahgari, P.R., Gaudio, R., Dey, S., 2017. Interference of an upstream pier on local scour at downstream piers. Acta Geophysica, 65, 1, 29-46.

Ling, J., Lin, X., Zhao, H., 2007. Analysis of three-dimensional flow field and local scour of riverbed around cylindrical pier. Nature Science, Journal of Tongji University, 35, 5, 582-586.

Link, O., Garcia, M., Pizarro, A., Alcayaga, H., Palma, S., 2020. Local scour and sediment deposition at bridge piers during floods. Journal of Hydraulic Engineering, 146, 3, Article Number: 04020003.

Melville, B.W., Coleman, S.E., 2000. Bridge Scour. Water Resources Publications.

MTPRC, 2004. General Specifications for Design of Highway Bridges and Culverts (JTG D60-2004). Ministry of Transport of the People's Republic of China.

Munteanu, A., 2004. Scouring around a cylindrical bridge pier under partial ice-covered flow conditions. University of Ottawa, Canada.

Munck, S.D., Gauthier, Y., Bernier, M., Chokmani, K., Legare, S., 2017. River predisposition to ice jams: a simplified geospatial model. Natural Hazards and Earth System Sciences, 17, 7, 1033-1045.

Namaee, M.R., Sui, J., 2019a. Impact of armour layer on the depth of scour hole around side-by-side bridge piers under ice-covered flow condition. Journal of Hydrology and Hydromechanics, 67, 3, 240-251.

Namaee, M.R., Sui, J., 2019b. Effects of ice cover on the incipient motion of bed material and shear stress around side-byside bridge piers. Cold Regions Science \& Technology, 165, Article Number: 102811. 
Namaee, M.R., Sui, J., 2019c. Local scour around two side-byside cylindrical bridge piers under ice-covered condition. International Journal of Sediment Research, 34, 4, 355-367.

Namaee, M.R., Sui, J., 2020. Velocity profiles and turbulence intensities around side-by-side bridge piers under icecovered flow condition. Journal of Hydrology and Hydromechanics, 68, 1, 70-82.

Schendel, A., Hildebrandt, A., Goseberg, N., Schlurmann, T., 2018. Processes and evolution of scour around a monopile induced by tidal currents. Coastal Engineering, 139, 65-84.

Sonia Devi, Y., Barbhuiya, A.K., 2017. Bridge pier scour in cohesive Soil: a review. Sadhana, 42, 10, 1803-1819.

Sui, J., Fang, D., Wang, D., 1994. Accumulation and evolution of frazil ice jam. Chinese Journal of Hydraulic Engineering, $25,8,42-47$.

Sui, J., Wang, J., Karney, B.W., 2000. Sediment concentration and deformation of riverbed in a frazil jammed river reach, Canadian Journal of Civil Engineering, 27, 6, 1120-1129.

Sui, J., Faruque, M.A.A., Balachandar, R., 2009. Local scour caused by submerged square jets under model ice cover. Journal of Hydraulic Engineering, 135, 4, 316-319.

Sui, J., Wang, J., He, Y., Krol, F., 2010. Velocity profiles and incipient motion of frazil particles under ice cover. International Journal of Sediment Research, 25 , 1, 39-51.

Tyminski, T., 2010. Hydraulic model research on bridge piers based on the example of selected bridges in Opole. Rocznik Ochrona Srodowiska, 12, 879-893.

Urroz, G.E., Ettema, R., 1992. Bend ice jams: laboratory observations. Canadian Journal of Civil Engineering, 19, 855864.

Urroz, G.E., Schaefer, J., Ettema, R., 1994. Bridge-pier location and ice conveyance in curved channels. Journal of Cold Regions Engineering, 8, 2, 66-72.

Wang, J., Sui, J., Karney, B.W., 2008. Incipient motion of noncohesive sediment under ice cover - An experimental study. Journal of Hydrodynamics, 20, 1, 117-124.

Wang, J., Chen P., Yang, Q., 2015. Impact of bridge piers on ice jam stage variation: An experimental study. Advances in Water Science, 26, 6, 867-873.
Wang, J., Hua, J., Sui, J., Wu, P., Liu, T., Chen, P., 2016. The impact of bridge pier on ice jam evolution: an experimental study. Journal of Hydrology and Hydromechanics, 64, $1,75-82$.

Wang, J., Wang, T., Li, S., Chen, P., 2017. Impacts of bridge pier on ice jam initiation and ice thickness in a curved channel-an experimental study. Chinese Journal of Hydraulic Engineering, 48, 5, 588-593.

Wang, J., Li, S., Chen, P., Sui, J., 2018. Impacts of bridge piers on water level during ice jammed period in bend channel: an experimental study. Journal of Hydrodynamics, 30, 1, 160168.

Wei, Y., Ye, Y., Wu, K., 2015. 3D numerical modeling of flow and scour around a circular pile. The Ocean Engineering, 4, 65-70.

Wu, P., Hitshfield, F., Sui, J., Wang, J., Chen, P., 2014. Impacts of ice cover on local scour around semi-circular bridge abutment. Journal of Hydrodynamics, 26, 1, 10-18.

Wu, P., Hitshfield, F., Sui, J., 2015. Armour layer analysis of local scour around bridge abutments under ice cover. River Research and Applications, 31, 6, 36-746.

Yang, Y., Melville, B.W., Macky, G.H., Shamseldin, A.Y., 2020. Temporal evolution of clear-water local scour at aligned and skewed complex bridge piers. Journal of Hydraulic Engineering, 146, 4, Article Number: 04020026.

Zabilansky, L.J., Hains, D.B., Remus, J.I. 2006. Increased bed erosion due to ice. In: Current Practices in Cold Regions Engineering, pp. 1-12.

Zaid, M., Yazdanfar, Z., Chowdhury, H., Alam, F., 2019. A review on the methods used to reduce the scouring effect of bridge pier. Energy Procedia, 160, 45-50.

Zhu, Z., Liu, Z., 2011. Three-dimensional numerical simulation for local scour around cylindric bridge pier. China Journal of Highway and Transport, 24, 2, 42-48.

Received 17 January 2021 Accepted 2 June 2021 